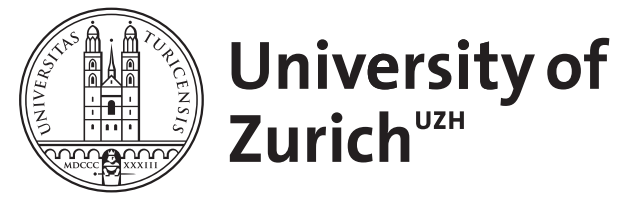
Archive

University of Zurich

University Library

Strickhofstrasse 39

CH-8057 Zurich

www.zora.uzh.ch

Year: 2014

Life, But Not as We Know It. Death and the Wax Image

van Gastel, Joris

DOI: https://doi.org/10.1515/9783110364804.231

Posted at the Zurich Open Repository and Archive, University of Zurich

ZORA URL: https://doi.org/10.5167/uzh-158556

Book Section

Published Version

Originally published at:

van Gastel, Joris (2014). Life, But Not as We Know It. Death and the Wax Image. In: Marienberg, Sabine; Trabant, Jürgen. Bildakt at the Warburg Institute. Berlin: De Gruyter, 231-251.

DOI: https://doi.org/10.1515/9783110364804.231 
Joris van Gastel

\section{LIFE, BUT NOT AS WE KNOW IT}

Wax Images and the Denial of Death"

On the second of April, 1635, the young Roman patrician Giacinto Centini was put to death on the Campo dei Fiori in Rome for an attempt on the life of Pope Urban VIII. ${ }^{1}$ The events leading up to his execution can be reconstructed with some detail, though for the present argument, some fragments from the sentence pronounced on the day of the execution may suffice.

[...] you, Giacinto, son of the late Giovanni Centini d'Ascoli, 38 years of age, are under the grave suspicion for this holy tribunal of having invited to your villa in Spinetoli, [...] brother Bernardino Montalto, a man excellent in the art of necromancy, who told you that your uncle should be pope as was your wish and, having seen and considered the prophecies of the abbot Giovachino, he affirmed that after the present pope [Urban VIII] your uncle would be pope, and that only you would need the heart to make it so, and that you could have the present pope die at your wish, for which he would make a statue of wax that, when subsequently it would be consumed, would result in the pope's death, and in order to do so, in the said villa of yours a convocation was planned where circles and characters were drawn to constrain a spirit. ${ }^{2}$

Research for this paper was made possible by a fellowship graciously granted by the Kolleg-Forschergruppe Bildakt und Verkörperung, Berlin. Earlier versions have been presented at the Sculpture and Animation workshop at the Courtauld Institute of Art and the EnBAch conference Baroque Bodies in Vienna; on both occasions I received helpful comments. Moreover, I wish to thank Philipp Zitzlsperger for a stimulating exchange of ideas and Katrin Weleda for providing me with a number of significant references. Unless otherwise indicated, translations are mine. Peter Rietbergen: Power and Religion in Baroque Rome. Barberini Cultural Policies, Leiden 2006, pp.349-360; Gino Benzoni in: Mario Caravale (ed.): Dizionario biografico degli italiani, vol. 23, Rome 1979, s.v., "Centini, Giacinto."

Biblioteca Nazionale di Roma [BNR], Fondo Sessoriano 270/1483; quoted in Michele Rosi: La congiura di Giacinto Centini contro Urbano VIII, in: Archivio della R. società 
And indeed, "the said brother Bernardino [...] shaped a statue of virgin wax of the present pope with mitre and pluvial," the whole setup was prepared, with circles and characters, a special dagger was casted to stab the wax image, and a fire was made to have it melt away. ${ }^{3}$ One father Cherubino held the image to the fire, but at the moment supreme he burnt his fingers and dropped the image into the flames. A spirit failed to appear, pope Urban VIII reigned for another 14 years, and Giacinto's uncle died of natural causes before any ascension to the papal throne was even possible.

Gian Lorenzo Bernini's striking marble portrait of the same pope had seen the light only a few years before Centini's execution. ${ }^{4}$ (Fig. 1) Already at the time, the bust was praised for its striking vivaciousness. "It is alive, alive, Bernini, Urban's sacred head," one poet exclaimed. ${ }^{5}$ Another author went a step further, arguing that Bernini, "with his own hands," had "transformed a piece of marble into His Holiness himself". ${ }^{6}$ In the light of the events described above, such common expressions of praise become somewhat ironic, as the suggested conflation of portrait and prototype is obviously not without its dangers. To understand how the marble portrait could nonetheless flourish in the early modern period, it becomes pertinent that we consider the relation between marble and wax. As several scholars have noted, the wax image has a problematic position in the history of art. Bernini himself considered it a cosa di donne, a thing for women, and even though he was clearly impressed by the colored waxes by

romana di storia patria 22 (1899), pp. 366f.: "Essendo che tu Giacinto figlio del quondam Giovanni Centini d'Ascoli, d'anni 38, fusti gravemente inditiato in questo santo tribunale d'haver fatto venire alla tua villa di Spinetoli, territorio d'Ascoli, del 1630, fra Bernardino Montalto, huomo eccellente dell'arte di negromantia, acciò ti dicesse se tuo zio dovesse esser papa come desideravi, et havendo vedute et considerate le profetie dell'abbate Giovachino, affermò che, dopo il presente pontefice, tuo zio sarebbe papa, e che gli bastasse l'animo d'oprare che riuscisse papa il detto tuo zio, et di far perciò morire il papa presente quando a lui piaceva, mentre egli havesse formata una statua di cera, la quale poi consumandosi sarebbe morto il papa, che perciò in detta tua villa si fece una convocatione con circoli et caratteri per costringere un spirto con l'intervento \& $c$." "una statua di cera vergine del presente papa con mitra e piviale". Sebastian Schütze in: ex.cat.: Bernini scultore. La nascita del barocco in casa Borghese, ed. by Anna Coliva/Sebastian Schütze, Galleria Borghese, Rome 1998, pp. 242-251 (with further bibliography on p. 242).

5 Pier Francesco Paoli: Rime varie, Rome 1637, p. 210: "Vivo, vivo è, Bernino, / Sacro il volto d'Urbano, / Opra de la tua mano".

6 Letter from Lelio Guidiccioni to Cav. Giovan Lorenzo Bernini, June 4th, 1633, in: Biblioteca Apostolica Vaticana [BAV], Barb. Lat. 2958, quoted in Joris van Gastel: Il marmo spirante. Sculpture and Experience in Seventeenth-Century Rome, Berlin/ Leiden 2013, p. 214 [f. 203v, 8]: "havendo di sua mano cambiato un marmo in Sua Santità medesima". 


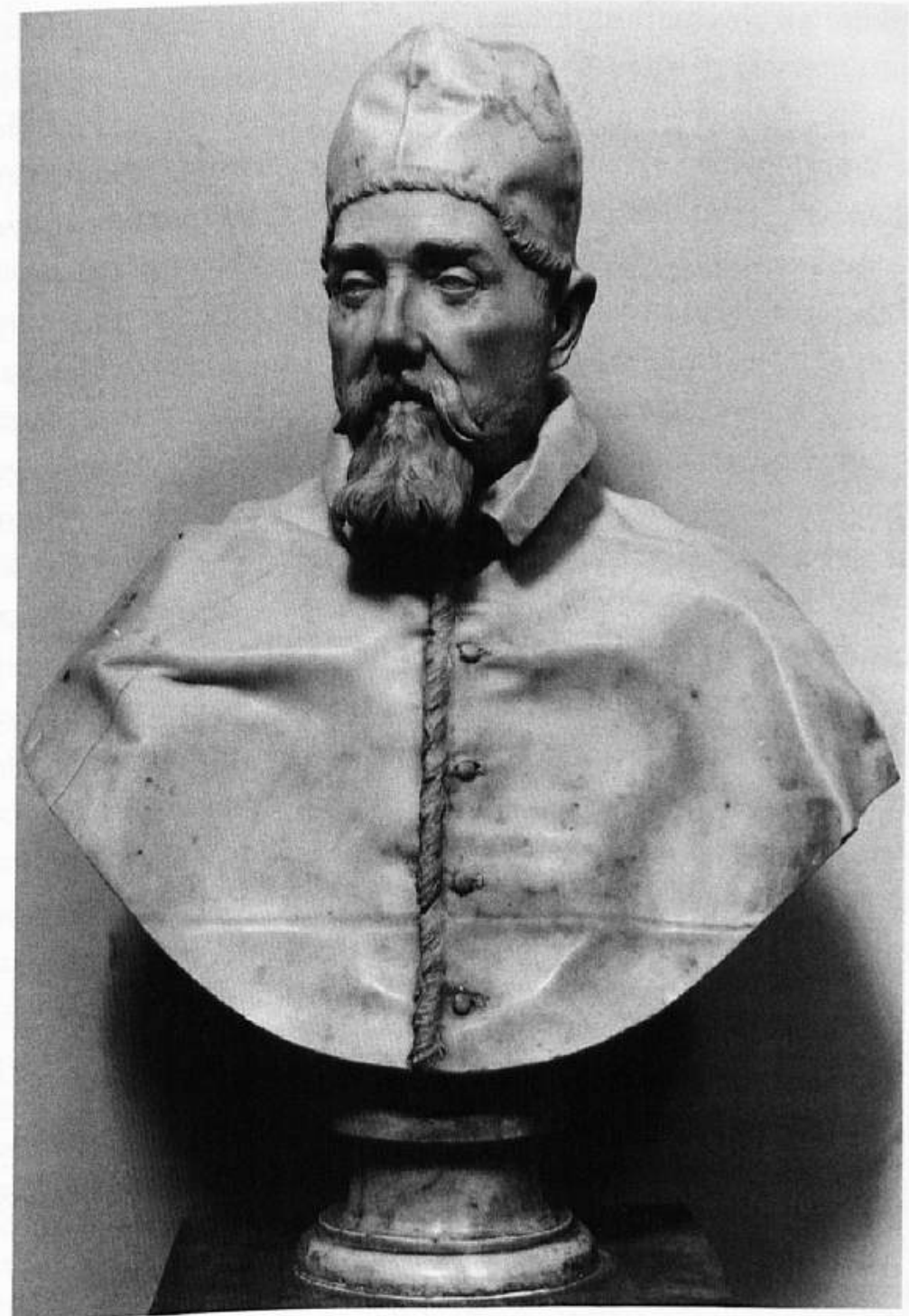

Fig. 1 Gian Lorenzo Bernini: Bust of Pope Urban VIII, 1632, marble, $83 \mathrm{~cm}$, Rome, Palazzo Barberini.

Antoine Benoît which he saw during his stay in Paris, he could not refrain from remarking that they "would particularly appeal to lovers." In other words, the artist subtly places it outside the realm of serious art, foregoing any exchange between "real art" and the wax image.

Paul Fréart Seigneur de Chantelou: Journal de voyage du cavalier Bernin en France, ed. by Milovan Stanić, Paris 2001, p. 143; ibid., p. 259: "ces portraits étaient pour plaire beaucoup aux personnes qui s'entr'aiment." For the negative connotations of the feminine in art, see Philip Sohm: Gendered Style in Italian Art Criticism from Michelangelo to Malvasia, in: Renaissance Quarterly 48 (1995), pp. 759-808. 
It is, then, all the more significant that in his 1902 essay Bildniskunst und Florentinisches Bürgertum Aby Warburg sought to explain the rise of the renaissance individualized portrait in Florence by looking at what he called the "fetishism of the waxwork cult." ${ }^{\text {"8 }}$ Like the many wax votive images that crowded the church of the Santissima Annunziata, he argued, so too the painted portraits were to make the portrayed present in the vicinity of the Divine. ' Warburg focuses on what we may call a pre-Vasarian association between waxwork and portrait, something that, arguably, was specific for this particular moment in history. A parallel and not unrelated development took place in the field of portrait sculpture, where the experiment of the first lifelike portrait busts involved an explicit engagement with death masks. ${ }^{10}$ However, these associations between waxwork and portrait, death mask and bust, were short-lived. Where, in following centuries, death masks were used for portrait busts, the association was carefully avoided. As much is suggested in a letter, dated 1561 and addressed to Alvise Contarini, concerning a portrait of his uncle Cardinal Gasparo Contarini to be made after his death mask. "It will be necessary," writes the sender, "to first cast it in clay or wax, and then to remove from it that appearance of death, which every master who is not an idiot will know how to do [...]."11

With regard to the wax portrait, the association with death appears less easy to dispose of. As Julius von Schlosser indicates at the outset of his classic

Aby Warburg: Bildniskunst und Florentinisches Bürgertum, Leipzig 1902, p. 11; trans. id.: The Renewal of Pagan Antiquity. Contributions to the Cultural History of the European Renaissance, trans. by David Britt, Los Angeles 1999, p. 190.

For a further underpinning of this argument, see Robert Maniura: Ex Votos, Art and Pious Performance, in: Oxford Art Journal 32 (2009), pp. 409-425. On ex votos see also Megan Holmes: Ex-votos. Materiality, Memory, and Cult, in: Michael Wayne Cole/Rebecca Zorach (eds.): The Idol in the Age of Art. Objects, Devotions and the Early Modern World, Surrey/Burlington 2009, pp. 159-181; Roberta Panzanelli: Compelling Presence. Wax Effigies in Renaissance Florence, in: Roberta Panzanelli (ed.): Ephemeral Bodies. Wax Sculpture and the Human Figure, Los Angeles 2008, pp.13-39; Hugo van der Velden: Medici Votive Images and the Scopes and Limits of Likeness, in: The Image of the Individual. Portraits in the Renaissance, ed. by Nicholas Mann/Luke Syson, London 1998, pp. 126-137. Jeanette Kohl: "Vollkommen ähnlich". Der Index als Grundlage des Renaissanceporträts, in: Similitudo, ed. by Martin Gaier/Jeanette Kohl/Alberto Saviello, Paderborn 2012, pp. 181-206; Panzanelli: Compelling Presence (as fn. 9); Jeanette Kohl: Gesichter machen. Büste und Maske im Florentiner Quattrocento, in: Marburger Jahrbuch für Kunstwissenschaft 34 (2007), pp. 77-99.

Letter from Ludovico Beccadelli to Alvise Contarini, January 4th, 1561, quoted in Gigliola Fragnito: Memoria individuale e costruzione biografica. Beccadelli, Della Casa, Vettori alle origini di un mito, Urbino 1978, pp. 19f., fn. 18: "sarà bisogno com'ho detto gittarlo in prima, o di creta, o di cera, et torgli poi quello aspetto di morto, il che saprà far ogni maestro che non sia goffo". Cf. Thomas Martin: Alessandro Vittoria and the Portrait Bust in Renaissance Venice. Remodelling Antiquity, Oxford 1998, cat. 69. 
study on the wax portrait, in religious contexts, the art of ceroplastics has been related to two "closely interrelated" sets of ideas: "the relationship of the living individual to the deity" - here we may think of Warburg's voti - "and that of the dead to the Beyond [...]." Moreover, he notes that these sets of ideas are "born of primitive psychology." ${ }^{12}$ As to the nature of this psychology, however, the reader is kept in the dark. Schlosser speaks of "superstitious reasoning" and "sympathetic magic," though it remains unclear what he precisely means by this. ${ }^{13}$ Strikingly, these considerations do not play much of a role in Schlosser's discussion, at the end of his essay, regarding the exclusion of wax portraiture from art history. Rather, opposing it to a classicist, idealist aesthetic, he argues: "Portraiture in wax was naively realistic, was given to quite uninhibited use of color and of natural materials, and took simple imitation (l'imitation simple) to the most extreme lengths possible." ${ }^{14}$ The question remains, then, to what extent there is any specific role for the material of wax and its relationship with magical thinking.

More recently, also Georges Didi-Huberman has stressed the absence of the wax image in art-historical discourse, attributing this "censorship," as he calls it, to the material's ambiguous nature, its "aesthetic viscosity," which results in a "dual uneasiness of degradation and excess." ${ }^{15}$ For Didi-Huberman, it is these particular material qualities that relate it to Sigmund Freud's concept of the uncanny. In fact, Freud, here following Ernst Jentsch, does mention the impression made by waxwork figures in his well-known essay on the uncanny, but relates this impression not so much to the material itself as (quoting Jentsch) to "doubts whether an apparently animate being is really alive; or conversely, whether a lifeless object might not, in fact, be inanimate [...]."16 With this, the

Julius von Schlosser: Tote Blicke. Geschichte der Porträtbildnerei in Wachs. Ein Versuch, ed. by Thomas Medicus, Berlin 1993, p. 13; trans. id.: History of Portraiture in Wax, trans. by James Michael Loughridge, in: Panzanelli (ed.): Ephemeral Bodies (as fn. 9), p. 175. More generally on wax and wax images: Jessica Ullrich: Wächserne Körper. Zeitgenössische Wachsplastik im kulturhistorischen Kontext, Berlin 2003; Charlotte Angeletti: Geformtes Wachs. Kerzen, Votive, Wachsfiguren, Munich 1980; Reinhard Büll: Das große Buch vom Wachs. Geschichte, Kultur, Technik, 2 vols., Munich 1978; Reinhard Büll: Keroplastik. Ein Einblick in ihre Erscheinungsformen, ihre Technik und Ästhetik, in: id (ed.): Vom Wachs. Hoechster Beiträge zur Kenntnis der Wachse 1, Frankfurt/M. 1963, pp. 417-526. Schlosser: History of Portraiture in Wax (as fn. 12), p. 176.

Ibid., p. 296.

Georges Didi-Huberman: Viscosities and Survivals. Art History Put to the Test by the Material, in: Panzanelli (ed.): Ephemeral Bodies (as fn. 9), pp. 154-169. Cf. Christine Göttler: Last Things. Art and the Religious Imagination in the Age of Reform, Turnhout 2010, pp. 219, 253-254.

Sigmund Freud: Das Unheimliche, in: Gesammelte Werke, ed. by Anna Freud, London 1947, vol.12, pp. 227-268, p. 237, engl. The 'Uncanny', in: The Standard Edition of the Complete Psychological Works, trans. by James Strachey, London 
question remains open whether these doubts are the result of an excess of naturalism, or suggest that we should, as Didi-Huberman's concept of degradation appears to imply, rather look for something which goes beyond the question of representation.

\section{The Denial of Death}

This paper will argue that an answer should be sought in anxieties related to our own corporal existence and mortality. As Hans Belting has shown in his 2001 Bild-Anthropologie, rituals surrounding absence and death, and more in general the questions of how people deal with death, are central to the power of images. ${ }^{17}$ To further explore the specific role of death, we may refer to Ernest Becker's book The Denial of Death of 1973, as well as to more recent experimental research that takes this book as a point of departure, however sidestepping its strong psychoanalytic tone ${ }^{18}$ Becker's central thesis is that, in order to cope with daily life, we develop strategies to suppress or deny our own mortality from early on. The ways in which we frame our own existence as well as the world at large block out eminent death, introduce an illusion of control, and transpose our faith to a higher being. When, coincidently, we are made aware of our mortality, we cling even harder to the ideas that we have built up to guard our egos.

Most important for our discussion is Becker's point that our tendency to buffer death anxiety also implies a problematic relationship to the human body. Man's body, he writes, "is a material fleshy casing that is alien to him in many ways - the strangest and most repugnant way being that it aches and bleeds and will decay and die." ${ }^{\prime 19}$ A similar point is developed by Julia Kristeva in her Powers of Horror. Echoing Céline's repeated reminder that we are "nothing but packages of tepid, half-rotted viscera," she defines the corpse as "the most sickening of wastes" and "death infecting life," presenting it as the horizon of our identity that, unsuccessfully, we attempt to fight off. ${ }^{20}$ More recently, Jamie Goldenberg and her colleagues have explored further implications of Becker's ideas, arguing that current phenomena such as the lavish use of Photoshop to alter the appearance of the body in the media, but also depilation - we will return to the role of

1999, vol. 17, p. 226. Cf. Ernst Jentsch: Zur Psychologie des Unheimlichen, in: Psychiatrisch-neurologische Wochenschrift 8 (1906), pp. 195-198, 203ff., here p. 197 and on waxworks p. 198. Hans Belting: Bild-Anthropologie. Entwürfe für eine Bildwissenschaft, Munich 2001, part. pp. 143-188. Ernest Becker: The Denial of Death, New York 1973.

19 Ibid., p. 26. New York 1982, p. 3; Louis-Ferdinand Céline: Journey to the End of the Night, trans. by Ralph Manheim, New York 1983, p. 291. 


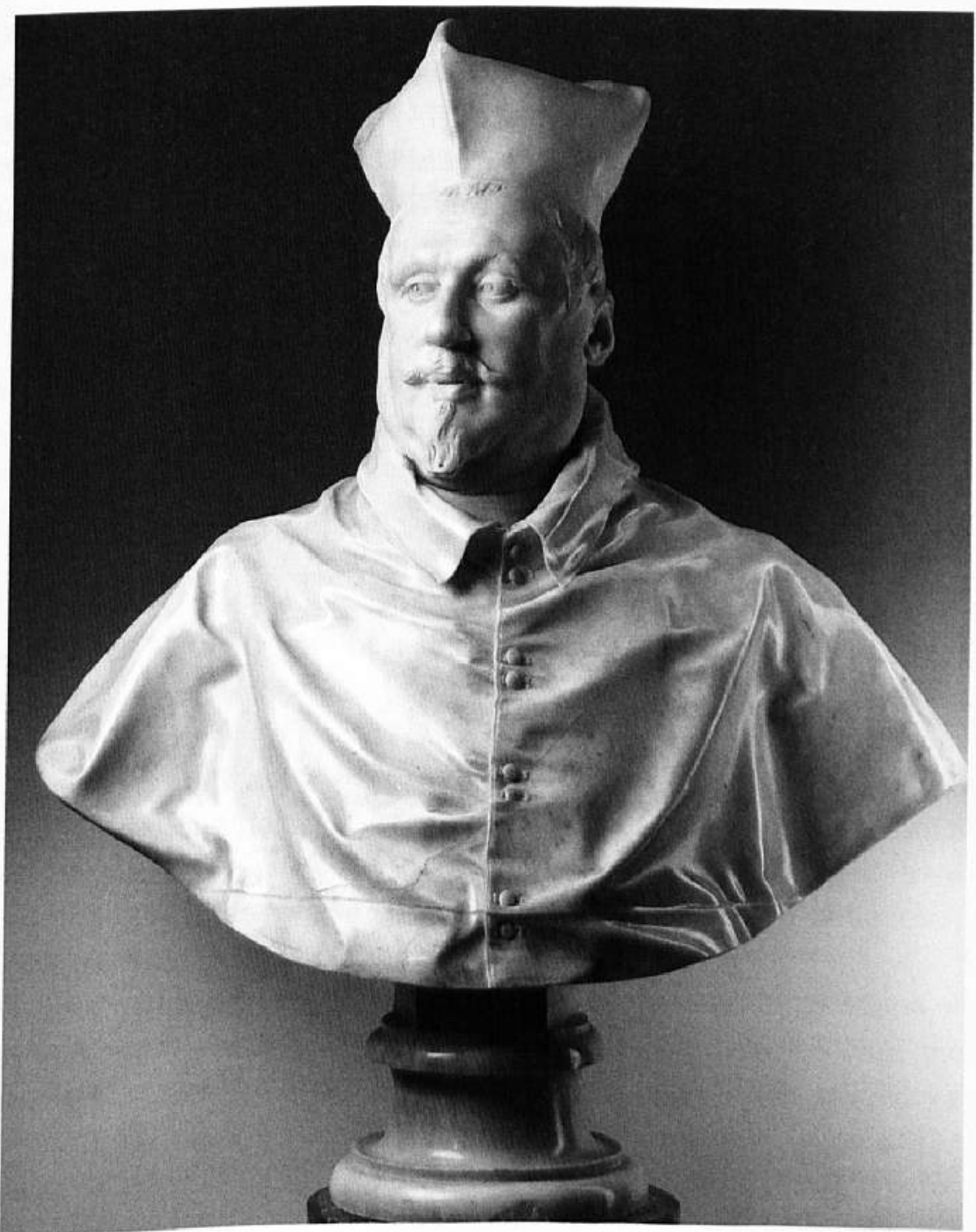

Fig. 2 Gian Lorenzo Bernini: Bust of Cardinal Scipione Borghese, 1632, marble, $80,1 \mathrm{~cm}$ (without base), Rome, Galleria Borghese.

hair below - and plastic surgery, can be understood as ways of objectifying the body, thus blocking out associations of decline and decay. ${ }^{21}$

Art, and particularly sculpture, it may be argued, is susceptible to similar processes of objectification. As already Leon Battista Alberti suggested, the portrait is inevitably tied up with death, indeed a point also Freud hints at when

Jamie L. Goldenberg et al.: Fleeing the Body. A Terror Management Perspective on the Problem of Human Corporeality, in: Personality and Social Psychology Review 4/3 (2000), pp. 200-218. 
he relates the ancient Egyptian practice of making "images of the dead in some lasting material" to the "invention of doubling as a preservation against extinction." 22 That such a concern was prevalent also in the seventeenth century becomes immediately clear when we look at the ways in which the marble portrait is treated in contemporary poetry. A striking example comes from the pen of poet Pier Francesco Paoli, in a sonnet written in praise of Bernini's Bust of Cardinal Scipione Borghese. (Fig. 2)

Vivo è Scipio in quel marmo,

E vivrà eterno ancor con doppia palma

Ne la corporea salma;

Che rivolta la Parca al vivo sasso

Stenderà in lui la mano,

E credendo haver casso

Di vita il gran Borghese,

Non s'armerà, per le seconde offese.

Bernin, che deve a te 'l Heroe sovrano,

Se fai nel marmo impresso

Vivo il suo volto, ed immortal lui stesso ${ }^{23}$

[Alive is Scipio in that marble, / and he will live for all eternity with double glory / in the corporeal body; / for Death, turning to the living stone, / will reach out to him / and believing to have drained / of life the great Borghese, / he will not arm himself for a second assault. / Bernini, how much must he not owe to you, that sovereign hero, / now that you have impressed in the marble, / his living face, and [made] him immortal?]

The poem can be understood in terms of Freud's idea of "doubling" (taken from Otto Rank) as a means to overcome the fears instilled by our mortality -indeed, its concetto is precisely that the double is here devised to overcome inevitable death. ${ }^{24}$ There is something particular to the material that appears to underline fn. 16), p. 235. Cf. Joanna Woodall: Hieronymus Cock's Effigies. Living Presence in Portrait Prints after the Death of the Original Model, in: The Secret Lives of Artworks, ed. by Caroline van Eck/Joris van Gastel/Elsje van Kessel, Leiden 2014, pp. 262-289; Belting: Bild-Anthropologie (as fn. 17), pp. 143-188; David Rosand: Alcuni pensieri sul ritratto e la morte, in: Giorgione e l'umanesimo veneziano, ed. by Rodolfo Pallucchini, Florence 1981, pp. 298-308. 
this time-transgressing quality. As marble, the "living stone," has the apparent ability to remain untouched by the teeth of time, the choice to keep its material visible seems particularly poignant. The absence of polychromy, then, more than any remnant of ancient tradition, can be said to be an actual necessity for the work to be understood in terms of eternity; through the absence of color, it distances itself from the once living body as a body of flesh, prone to decay. ${ }^{25}$

A similar kind of distancing is much more difficult in the case of the wax image. ${ }^{26}$ The double's precarious relation to life and death is at stake in the wellknown anecdote recounted by Filippo Baldinucci in his biography of the Carrarese sculptor Pietro Tacca (1577-1640) regarding the latter's wax bust of Grand Duke Cosimo II. Adorned with "real eye lashes, beard, and hair, and eyes of crystal with such a colour [macchia] that they seemed his own," the portait, writes Baldinucci, seemed "not a feigned person, but real and alive." It was a life, though, that carried in it the association of the sitter's passing. After the premature death of the Grand Duke - he had died at age 31 - his mother, Cristina of Lorena, when visiting Tacca's house, "before doing so, ordered the portrait to be taken from its place, her heart not being able to bear to see again alive, but rather in a mute statue, her beloved son that had already fallen prey to death." ${ }^{27}$ Here, through the common conventions of praise, we sense a more profound getting to grips with the agency the wax image exercises on the spectator; "[f]rom having been an assurance of immortality," we may quote Freud for one last time, "it becomes the ghastly harbinger of death." ${ }^{28}$

If for Cristina of Lorena the wax image came to function as a kind of unsettling déjà-vu, on other occasions it was explicitly employed to capture the last flutterings of fleeting life. A case in point is presented by the events following the execution and decapitation of the fisherman Masaniello, leader of the Neapolitan revolt of 1647 . Cleaned up and sewn together, his body was exposed

Cf. ex. cat.: The Color of Life. Polychromy in Sculpture from Antiquity to the Present, ed. by Roberta Panzanelli/Eike D. Schmidt/Kenneth D. S. Lapatin, J. Paul Getty Museum, Los Angeles 2008; Frank Fehrenbach: Coming Alive. Some Remarks on the Rise of "Monochrome" Sculpture in the Renaissance, in: Source 30 (2011), pp. $47-55$.

26 Cf. Ullrich: Wächserne Körper (as fn. 12), pp. 149-198. Filippo Baldinucci: Notizie dei professori del disegno da Cimabue in qua, ed. by Ferdinando Ranalli/Paola Barocchi, vol. 4, Florence 1975, p. 99: "testa con busto del granduca Cosimo II, con ciglia, barba, e capelli veri, ed occhi di cristallo di tal macchia, che sembravano i suoi propri, e tutto il ritratto non persona finta, ma vera e viva $[$ sembrava]; $[\ldots]$ madama sereniss. Cristina di Lorena la madre $[. .$.$] entrata per$ suo diporto nella casa del Tacca per vedere l'opere sue, prima di farlo, ordinava, che si facesse togliere di luogo il ritratto, non soffrendole il cuore di tornare a vedere vivo, ma però in una muta statue, il caro figliolo già fatto preda della morte." The passage is discussed by Schlosser: Tote Blicke (as fn. 12), pp. $70 \mathrm{f}$. Freud: Das Unheimliche (as fn. 16), p. 247; trans. id.: The Uncanny (as fn. 16), p. 235. 
at the church of the Carmine where it was treated almost as that of a saint, people touching, even kissing the body or the sheets that covered it, some touching it with their rosaries. Tommaso De Santis writes in his account of the revolt how at the occasion portraits were made, not only painted but also sculpted in wax, the latter "extremely lifelike." "No sooner was he put up to be portrayed," he continues, "than a voice called out, saying that he had risen from the dead, and with a smiling face had publically blessed the people." 29 The wax portraits, then, here appear to assume the character of relics, not unlike the hairs torn from Masaniello's head by "many women," who saved them "at their chest, as if they were relics [...]." ${ }^{\prime 30}$ In a context where the boundary between life and death is transgressed, and a more personal transgression of boundaries is indicated by the ritualized touch of the lifeless body, the wax image takes up its role as double. Wax, then, functioned in contexts where people's relationship with death or rather the absence of such a relationship - was under pressure, that is, in contexts where death is irrefutable but at the same time challenged. What are the qualities of wax that allow it to take on this role? In the remainder of this paper, four interrelated perspectives will be discussed.

\section{Wax as Flesh}

"Was there ever anything that came so close to the real?" asks the poet Giovan Battista Marino rhetorically in his poem on a wax portrait of Cardinal Odoardo Farnese. ${ }^{31}$ Its liveliness, however, appears to reside not only in its appearance but also in the very wax itself. It is sculpted in viva cera, writes the poet, "in living wax." ${ }^{\prime \prime 2}$ It is true that, as we saw in Paoli's poem on Bernini's bust of Scipione Borghese, poets as easily write of living marble, but there is a significant difference between marble and wax, for while marble is alive only for the eyes, wax deceives also the sense of touch. ${ }^{33}$ In the popular story of Pygmalion in Ovid's 1647]: "Molti pittori fecero il suo ritratto, e ne furono formati ancora alcuni in cera molto al naturale: ogn'uno ne cercava, ogn'uno ne voleva uno, senza guardar' à prezzo. Mentr'era accomodato in postura di ritrarlo, eccoti sparsa una voce d'esser resuscitato, e che con faccia ridente avesse bendetto publicamente il Popolo."

Giuseppe Donzelli: Partenope liberata, Naples 1647, p. 67: "Molte donne gli strapparono i capelli, serbandogli in petto, come fussero Reliquie." Cf. ex. cat.: Civiltà del Seicento a Napoli, ed. by Silvia Cassani, Museo e Gallerie Nazionali di Capodimonte, Naples 1984, vol.2, p. 47. Giambattista Marino: La galeria, ed. by Marzio Pieri/Alessandra Ruffino, Trent 2005, p. 412: "Qual fu mai tanto al ver finto simile?" Ibid., p. 412. and Experience in Seventeenth-Century Rome, Berlin/Leiden 2013, pp. 135-167. 
Metamorphosis, we read how the sculptor's experience of the coming to life of the statue of Galathea under his touches is likened to that of molding hard wax, which, as recounted in a seventeenth-century Italian edition, "made more soft and warm with the fingers, in order to give it any kind of shape, becomes more and more tractable and less firm." ${ }^{\prime \prime 4}$ Here the evocation of the living flesh of the sculpture and the soft, warm wax overlap, and strengthen one another. In a more literal way, Giacomo Vivio assures Cardinal Alessandro Peretti di Montalto in his Discorso sopra la mirabil opera di basso rilievo that his portrait in colored wax "not only shows the color of skin [carnagione] to the eye, but will feel to the touch as your very own flesh." ${ }^{35}$

Conversely, flesh itself could have a wax-like quality to it. A seventeenthcentury biographer of Saint Francesca Romana, for example, wrote that, when her coffin was opened some four and half months after she had been buried, "almost all that were present touched and felt that blessed body, and her hands and arms, and they found that it moved easily, as were it a living body, or of soft wax [... $]^{\prime \prime 36}$ Of the blessed Colomba of Rieti it was said that when her body was recovered, her heart, bathing in blood still "full of life, bright and pure," was of a wax-like consistency. Her biographer could only explain this with reference to Psalm 22: "I am poured out like water, and all my bones are out of joint: my heart is like wax; it is melted in the midst of my bowels. [...] thou hast brought me into the dust of death. ${ }^{\prime \prime 37}$

Here, with the decaying bodies of saints, we are already in the context of death itself. Due to its flesh-like softness and the way it retains the heat of touching hands, wax is like flesh a transient substance, a substance that may ooze, break open, and wither away. It does not, then, seem to be a coincidence that the

The Italian translation in Publius Ovidius Naso: Le metamorfosi di Ovidio, Ridotte da Gio. Andrea dall'Anguillara, in ottava rima, ed. by M. Gioseppe Horologgi/ M. Francesco Turchi, Venice 1610, book 10, p. 157v: “Come se preme alcun la cera dura, / L'ammolla con le dita, e le riscalda, / E per poter donarle ogni figura, / Viene ogn'hor piu trattabile, o men salda".

Giacomo Vivio: Discorso sopra la mirabil opera di basso rilievo di cera stuccata con colori scolpita in pietra negra, Rome 1590, p. 8: "dimostra la carnagione, non solo al vedere; ma si rende al tatto come la propria carne". Cf. Maarten Delbeke: Matter Without Qualities? Wax in Giacomo Vivio's 'Discorso' of 1590, in: Sébastien Clerbois/Martina Droth (eds.): Revival and Invention. Sculpture through its Material Histories, Oxford 2011, pp. 91-120.

Virgilio Cepari: Vita di Santa Francesca Romana, Rome 1675, p. 363: "e quasi tutti toccarono, e palparono quel benedetto corpo, e le sue mani, e braccia, e le trovarono facili ad essere mosse, come se fosse stato corpo vivo, ò di cera molle". Sebastiano Bontempi in: Acta sanctorum, Maii V, Antwerp 1685, p. 389 [cap. LXI, 217]; quoted after Katharine Park: Holy Autopsies. Saintly Bodies and Medical Expertise, 1300-1600, in: Julia L. Hairston/Walter Stephens (eds.): The Body in Early Modern Italy, Baltimore 2010, p. 66. Cf. psalm 22:14. 


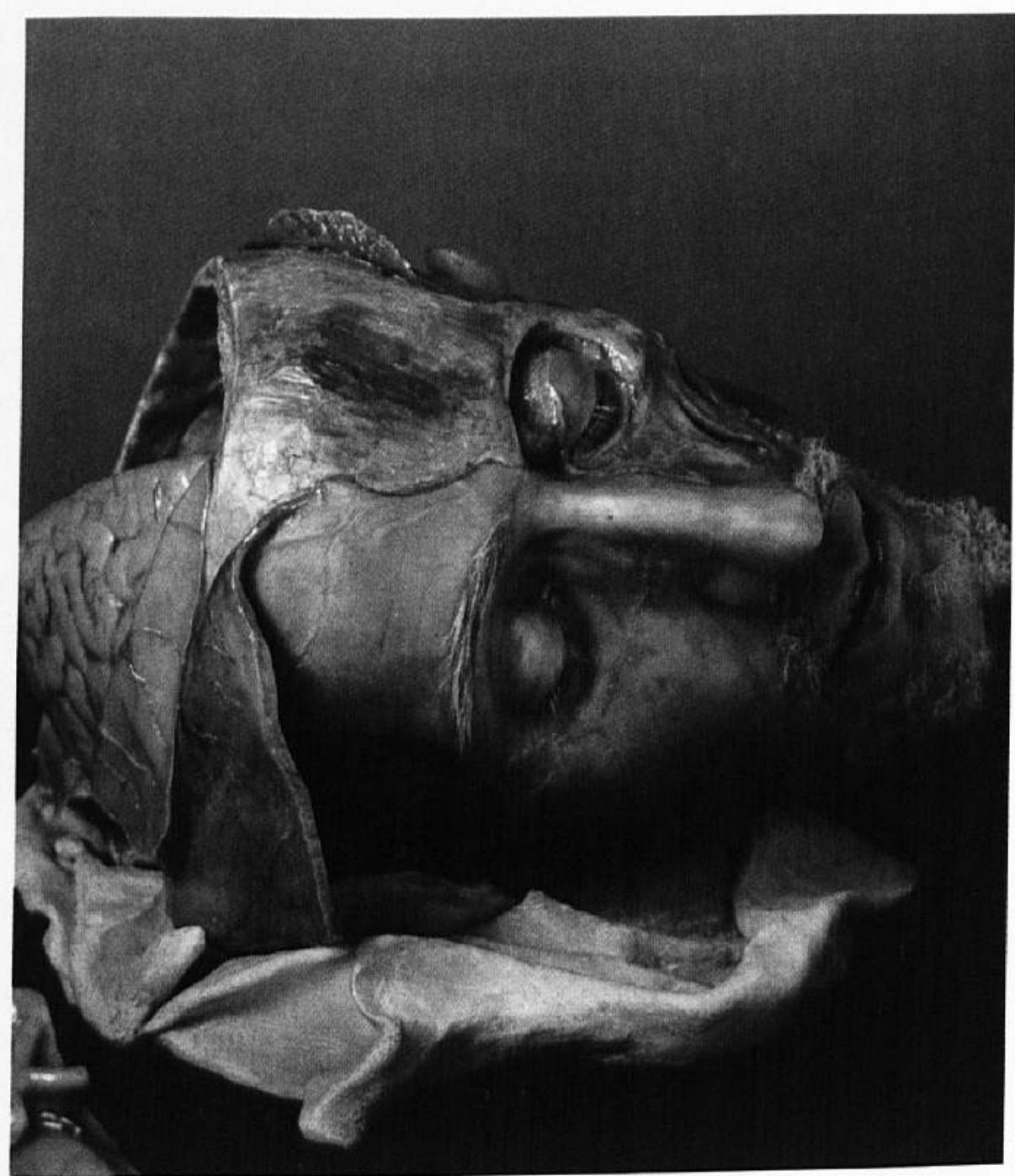

Fig. 3 Gaetano Zumbo: Anatomical Head, c. 1695, wax on a human skull, life size, Florence Museo della Specola.

Sicilian wax modeler Gaetano Zumbo, among the first to make colored anatomical wax models, thematizes the decay of flesh in his works. In his tableaus of the Plague and the Triumph of Time bodies in varied states of decay are strewn about, and even his anatomical head of a man, modeled around a real skull, has lost its freshness. ${ }^{38}$ (Fig. 3) With the almost closed eyes set in deep, bony sockets and parched dark skin, the man appears to hover between illness and death, an

Jane Eade: The Theatre of Death, in: Oxford Art Journal 36 (2013), pp. 109-125; Maria Grazia Cordua et al.: Mirabili orrori. Cere inedite di Gaetano Zumbo dopo il restauro, in: OPD restauro 21 (2010), pp. 71-87; Anja Wolkenhauer: "Grausenhaft wahr ist diese Geschichte". Die Wachsfiguren von Don Gaetano Zumbo zwischen Kunst und medizinischer Anatomie, in: Gabriele Dürbeck et al. (eds.): Wahrnehmung der Natur, Natur der Wahrnehmung. Studien zur Geschichte visueller Kultur 
image that is further strengthened by the drops of curdled blood in his left nostril and at the side of his mouth. In 1587, the young Dutch humanist Aernout van Buchel would note down his impression of the voti in the church of the Santissima Annunziata in Florence, writing that, at first entrance, it "appeared as a field of cadavers." ${ }^{\prime 39}$ Only in 1665 had the voti been moved from the church to a small cloister, and we may wonder whether Zumbo's depictions carried some of the associations of this spectacle.

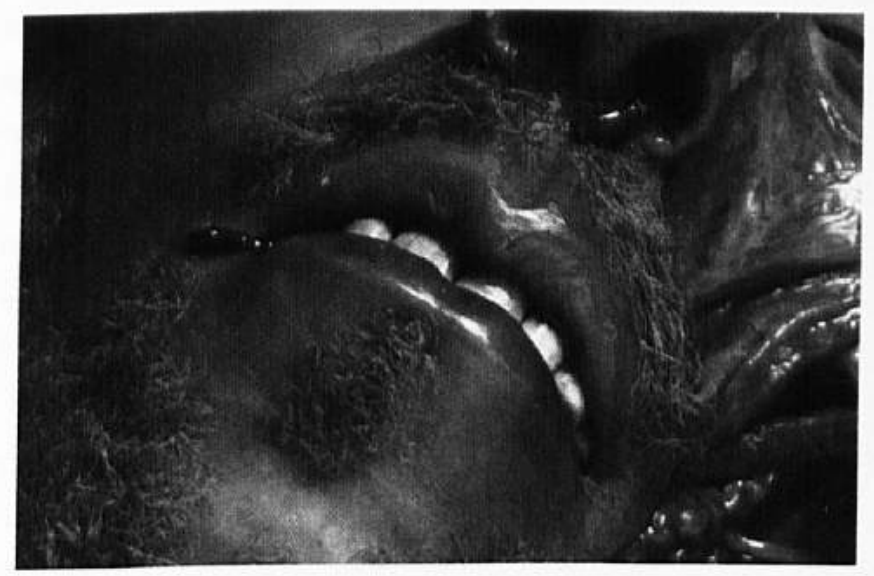

\section{Casts of Saints}

Throughout the early modern period, the wax portrait remained associated with the cast. The accounts of Pliny the Elder and Polybius of wax portraits of ancestors kept in the houses of Roman patricians and carried around in funeral processions were repeated time and again in early modern sources. ${ }^{40}$ These include Giovanni Baglione's Vite, where, not coincidently, it is mentioned in the biography of Rosato Rosati, a sculptor of wax portraits. ${ }^{41}$ Filippo Baldinucci refers to Pliny's account in his Notizie, where he gives it a central part in his brief history of portraiture that introduces the biography of Medici court portraitist Justus Sustermans. ${ }^{42}$ Vasari traces the origins of the modern portrait bust to Verrocchio's workshop, where the modeling of figures in wax "portrayed after

um 1800, Dresden 2001, pp. 71-85 (with further refences in fn. 1); Paolo Giansiracusa (ed.): Gaetano Giulio Zumbo, Milan 1988.

39 Arnoldus Buchellius: Iter italicum (1587), quoted in Warburg: Bildniskunst (as fn. 8), pp. 348f.: "ad primum ingressum cadaverorum campum crederes."

40 Pliny: Natural History, trans. Harris Rackham, vol.9, Cambridge, MA 1952, XXXV.ii.6; Polybius: The Histories, trans. by William R. Paton, vol. 3, Cambridge, MA 1923, VI.53.

41 Giovanni Baglione: Le vite de' pittori scultori et architetti, Vatican City 1995, vol. 1, pp. 173f. Baldinucci: Notizie (as fn. 27), vol. 4, p. 473. 
life and painted with oil" coincided with the making of death and life masks "made so well and natural that they seem to be alive."143

However, more often the wax casts functioned in a different context. In the life of Saint Filippo Neri written by Giacomo Pietro Bacci, for example, we read about the many wax casts of his face that were made "for the consolation of the many devotees that longed to have his effigy close to them [... ${ }^{\prime \prime 44}$ It has been suggested that a drawing in the Albertina, attributed to Guido Reni, depicts the saint as he could be seen when his body was excavated to make a new death mask. ${ }^{45}$ (Fig. 4) Even if the documents pertaining to this new cast leave some room for interpretation, the image is evocative and it should remind us that the making of a death mask involved a direct application of matter to the deteriorating face of the subject. And indeed, from accounts of the life and afterlife of Saint Camillo de Lellis (1550-1614, canonized 1746), we learn that the making of such a cast was not without danger: "in making the [...] mask, to great displeasure of the fathers, his face remained somewhat damaged, and burned, because the oil was too hot.."46

Returning to Filippo Neri, we may get an idea of the status of the wax death masks that were produced for the "many devotees" from the account of the display of a wax effigy at the Bolognese church of Santa Maria di Galliera during the celebrations of the Saint's canonization in 1622: “On the altar, between various reliquaries and other precious silver objects, stood in the middle a box of cypress wood, clothed all over with red satin lined with silver, in which was kept a wax effigy of the saintly Father, made on his very own face after the ties that bound his glorious soul and body had dissolved [...]."47

Giorgio Vasari: Le vite de' più eccelenti pittori scultori e architettori nelle redazioni del 1550 e 1568, ed. by Rosanna Bettarini/Paola Barocchi, vol.3, Florence 1966, pp. $543 f$. (ed. Giuntina).

Giacomo Pietro Bacci: Vita di S. Filippo Neri, Bologna 1666, p. 336: "per consolatione di molti divoti, che bramavano di haver' appresso di se la sua effiggie, fù permesso da' Padri, che ne fosse fatto il cavo in gesso: dal quale ne sono poi state gittate molte in cera, che lo raffigurano al naturale." Veronika Birke/Janine Kertész: Die Italienischen Zeichnungen der Albertina, vol.4, Vienna 1997, p. 2189, inv. 17665; Olga Melasecchi in: ex. cat.: La regola e la fama. San Filippo Neri e l'arte, ed. by Claudio Strinati, Museo Nazionale del Palazzo di Venezia, Milan 1995, p. 536, cat. 96. Mario Giuseppe Lanci: Vita del venerabile padre Camillo de Lellis, Mondovi 1671, p. 360: "Ancorche nel farsi la [...] maschera [di gesso] con grandissimo disgusto de' padri gli fosse restato alquanto offeso, \& abbruggiato il viso, per essere stato l'oglio troppa bollente". 1699, p. 16: "Nell'Altare frà varii reliquiarii, \& altre galanterie d'argento stava nel mezzo una cassa di cipresso soderata da per tut to di raso rosso co' suoi finimenti d'argento, in cui era una effigie di cera del Santo Padre fatta sù la sua faccia istessa dopo che l'anima gloriosa restò sciolta da' legami del corpo". 


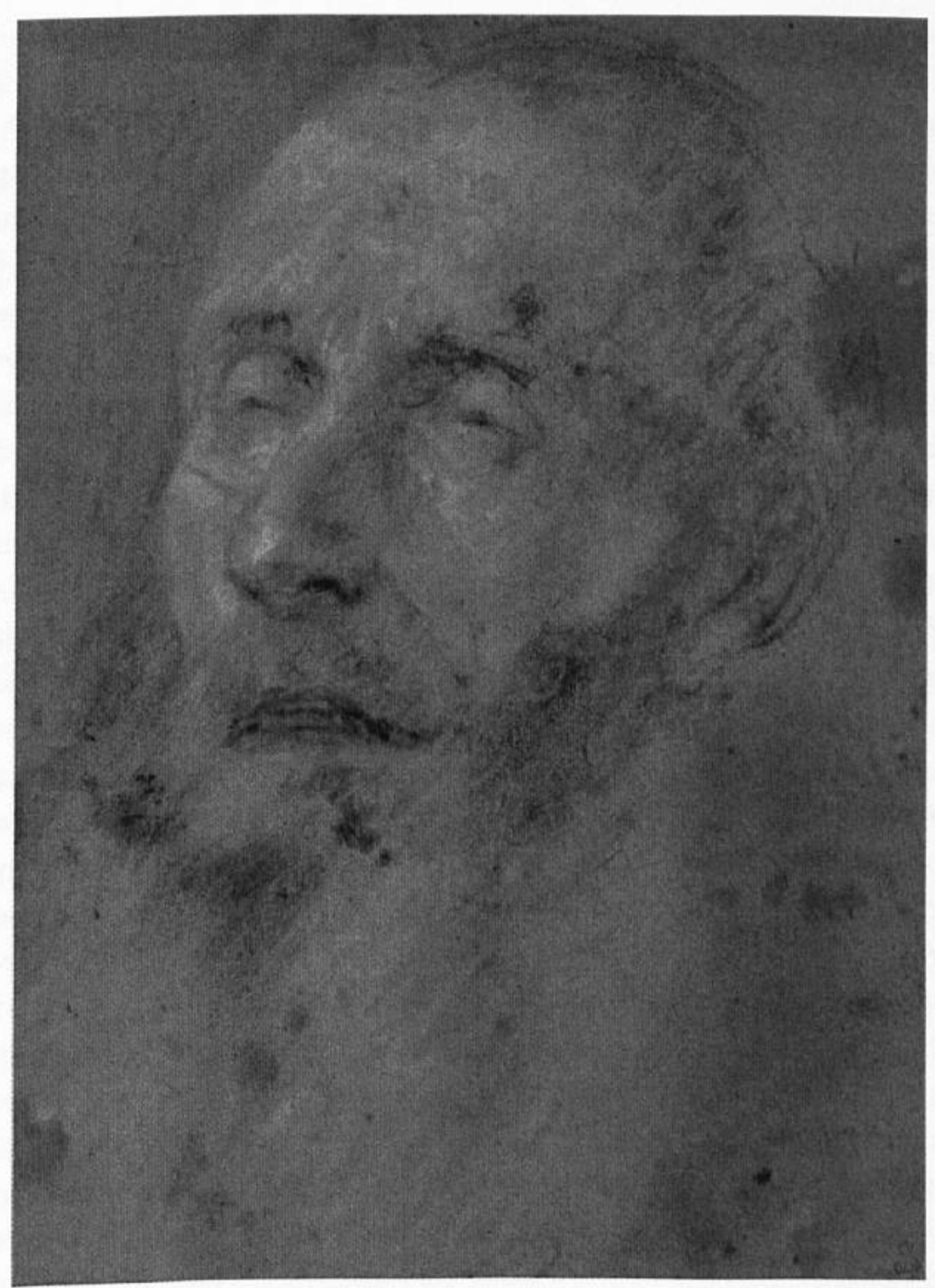

Fig. 4 Guido Reni, attr.: Saint Filippo Neri, 1614?, pastel colours on blue gray paper, $24,3 \times 17,8 \mathrm{~cm}$, Vienna, Albertina.

As this account illustrates, the wax mask was very much regarded, not as a work of art - above the altar was in fact a painted portrait of the saint - but rather as a relic. ${ }^{48}$ Indeed, the account makes very explicit the moment of touch; it was "made on his very own face," even if, in fact, the wax itself would never have touched it. 


\section{Wax and Magic}

If this association with the cast is something that appears to cling to the wax image in general, there is a further association that should be taken into account. To explore this, we must return to the use of wax images in magical practices, for if Centini's account is exceptional in its detail, it is certainly not unique. In his Anotomia d'amore profano of 1642, Matteo Palma warns for the power that women may gain over men by making use of images, speaking explicitly about wax portraits. Palma refers to Vergil: "As this clay hardens and as this wax melts in one and the same flame, so may Daphnis melt with love for me"; and also to Ovid's Medea: "She vows to their doom the absent, fashions the waxen image, and into its wretched heart drives the slender needle $[\ldots]]^{\prime \prime 49}$ And if this may seem to be something of a very distant past, also at the time, it soon becomes clear that they are to be taken very seriously. In fact, noting without further elaboration the popular accounts of witch trials penned down by Paolo Grillandi and Jacob Sprenger, Palma argues that they are indeed very true. ${ }^{50}$

An interesting case of such a use of wax can be found among the records of the Holy Office of Venice, where in 1588 a young lady named Elena Cumano stood trail for witchcraft. The accusation followed the discovery of a wax figure near the altar in the Cathedral of Feltre. What the priests celebrating Mass first thought to be a small child turned out to be a wax figure of a nude man, with "many needles stuck all over it, especially the eyes, temple, heart and phallus." Elena was soon found out, and declared that she had employed the figure to bring back her husband who had deserted her and fled to Flanders. We learn, moreover, that she had had the figure made by a local artisan named Pietro Grevo who, significantly, was in the business of making wax votive images. Pietro's testimony indicates that, after a first exemplar was rejected because it lacked "a virile member and testicles," he modified his moulds with beans to achieve these details. ${ }^{52}$ It will, at this point, come as no surprise that wax votive images, too, could be used to get at the portrayed. In fact, the destruction of the wax voto of pope Clement VII in the Santissima Annunziata was referred to by

Matteo Palma: Anotomia d'amore profano, Venice 1642, pp. 345f.; Virgil: Eclogues, Georgics, Aeneid, trans. by H. Rushton Fairclough, Cambridge, MA 1916, VIII.80; Ovid: Heroides and Amores, trans. by Grant Showerman, Cambridge, MA 1931, VI.9; cf. Daniel Ogden: Magic, Witchcraft, and Ghosts in the Greek and Roman Worlds. A Sourcebook, Oxford 2002. of the Renaissance, New York/Oxford 1993, p. 57. 
one contemporary as his "murder." ${ }^{\prime \prime 53}$ Of course, this is also confirmed by the attempt on the life of pope Urban VIII instigated by Giacinto Centini.

Although most accounts of magic involving wax are fairly unclear about what qualities of the material make it so suitable for use in such practices, common associations may at least help us formulate some hypotheses. In Girolamo Menghi's popular Compendio dell'arte essorcistica, reprinted at least thirteen times within fifty years following the first edition of 1576, we may read how wax, but also hair, nails, and lead, may be used by magicians to constrain daemons. ${ }^{54}$ Nor does this association with hair and nails seem to be a casual one. The disturbing case of a possessed woman, described by Antonio Benivieni at the beginning of the sixteenth century, involves her giving up "long, bent nails, bronze pins, together with hair and wax all mixed in a ball." ${ }^{\prime 55}$ Like wax, nails and hair are organic materials, though not actually alive. Moreover, the mentioning of wax among hair and nails suggests that the material may have similar taboo-like associations. Indeed, as James George Frazer already writes in his Golden Bough (1922), "[t]he notion that a man may be bewitched by means of the clippings of his hair, the parings of his nails, or any other severed portion of his person is almost world-wide." ${ }^{56}$ Often, Frazer's examples illustrate, they are associated with wax. ${ }^{57}$

\section{Infectious Matter}

To further understand the implications of this association, however, we should delve somewhat deeper into the discussion of hair, which, moreover, also is of interest for the wax portrait itself. Tacca's bust of Cosimo II, we may recall, had "real eye lashes, beard, and hair," as indeed holds true for Zumbo's Anatomical Head. As Janice Miller has pointed out, hair, and in particular disembodied hair, is something both familiar and alien; dissociated from the living body, it remains

Gio. Battista Busini: Lettere a Bemedetto Varchi sugli avvenimenti dell'assedio di Firenze, ed. by Gaetano Milanesi, Firenze 1860, p. 189: "anche tu ti trovasti ad ammazzare il papa nei Servi." Cf. ibid., p. 33 and Richard C. Trexler: Public Life in Renaissance Florence, New York/London 1980, p. 123.

Girolamo Menghi: Compendio dell'arte essorcistica, Venice 1605, pp. 65f.: "alcuna volta con certe cosette superflue, et di miuno valore facilmente [i demoni] si fanno mancipij, \& servi de' Maghi, \& incantatori; \& alcuna volta gli constringono ò nei capegli, ò nelle unghie, ò nella cera, ò nel piombo, overo con un debile filo li legano." Antonio Benivieni: De abditis nonnullis ac mirandis morborum et sanationum causis, Florence 1507, ch. 8, quoted and translated in Piero Camporesi: The Incorruptible Flesh. Bodily Mutation and Mortification in Religion and Folklore, trans. by Tania Croft-Murray/Helen Elsom, Cambridge 1988, p. 120. Ibid., p. 13. 
as a "reminder of the transient nature of the human body," but also as a relic, something once attached and touching, seemingly alive but in fact dead organic waste. ${ }^{58}$ Significantly, early modern accounts discuss body hair as "excrement," something that, like sweat, is excreted by the body and bears associations of infections and disease. ${ }^{59}$ Lucrezia Borgia's lock, once hidden between the papers of the poet Cardinal Pietro Bembo, may remind us of the fact that also in lyric poetry hair had a problematic status, shifting between sign of beauty and tormenting snare that binds the lover's soul. ${ }^{60}$

Recent research in psychology and biology indicates that hair, like nail clippings, intestines, wounds, and indeed dead bodies, evokes a response that is labeled with the emotion of disgust. Departing from an evolutionary account of human behavior, authors such as Paul Rozin have argued that disgust can be understood as a hard-wired behavioral defence against infection. ${ }^{61}$ Organic materials, and particularly those associated with the sick or decaying body, harbour the danger of infection and an inborn inclination to shy away from them is a good way to safeguard one's capacities to produce offspring. Although disgust does not seem to be directly related to the uncanny, scholars in the field of robotics have made precisely this connection in discussing responses to all too human androids. ${ }^{62}$ The common denominator is the role of death and, more specifically, that of the mortal body. The most forceful triggers of disgust appear to be directly related to the more animal side of our being.

Maybe surprisingly, the eyes too may have the kind of negative connotation evoking disgust, at least for the early modern public (though eyes also play a central role in E.T.A. Hoffmann's Der Sandmann of 1816, analyzed in detail by Freud in his essay on the uncanny and by Rank in his work on the double). ${ }^{63}$

Janice Miller: Hair Without a Head. Disembodiment and the Uncanny, in: Geraldine Biddle-Perry/Sarah Cheang (eds.): Hair. Styling, Culture and Fashion, Oxford/New York 2008, pp. 183-192; cf. ex. cat:: Cheveux chéris. Frivolités et trophées, ed. by Yves Le Fur/Odile Gilbert, Musée du Quai Branly, Paris 2012. Sandra Cavallo: Artisans of the Body in Early Modern Italy. Identities, Families and Masculinities, Manchester 2007.

See e.g. Francesco Petrarca: Canzoniere, ed. by Marco Santagata, Milan 1996, no. 197: "le chiome bionde, e' 1 crespo laccio, / che si soavemente lega et stringe / l'alma, che d'umiltate e non d'altr'armo."

For an overview see Valerie Curtis/Adam Biran: Dirt, Disgust, and Disease. Is Hygiene in Our Genes?, in: Perspectives in Biology and Medicine 44 (2001), pp. 17-31; cf., more generally, Winfried Menninghaus: Ekel. Theorie und Geschichte einer starken Empfindung, Frankfurt/M. 2002. pp. 33-35. 
Referring again to Menghi's text on witchcraft - though here he is not writing about witches in particular - we may read how runny and teary eyes may hurt [offendere] the person who meets their glance. "This comes about," he argues, "because their eyes, being infected with a bad quality [mala qualità], infect the air that is between the one and the other [person], and this infected air, in turn, infects the eyes that confront the eyes of the diseased." ${ }^{\prime \prime 4}$ A significant addition to this idea can be found in Gregorio Comanini's Il figino, an art-theoretical text published in 1591. Here, following the work of Marsilio Ficino, the author speaks of a "vapor of corrupt blood" that emanates from runny and bloodshot eyes, "contaminating with the same disease the eyes that meet them." ${ }^{\prime 65}$

With the eyes and hair we have arrived also at the adornment of the wax portrait; the real hair and eyelashes, the eerie glass eyes. As particularly the magical accounts we have discussed illustrate, however, the wax itself has very similar associations, seemingly appealing to the same mechanisms of disgust. Moreover, we may expect one to reinforce the other; in the wax image the uncanny and the abject appear to overlap. These are associations, then, that are deeply ingrained in the material itself, evoking responses that, though partially structured by culture, have their origins in deep-rooted instincts.

Wax straddles the dark line between life and death. In its adaptability, its fleshlike quality, its warm, organic nature, wax manages to cling on to life, to draw it in and retain it. And yet, wax, in being so close to life, is actually too close to death. The very material draws attention to the body as a physical body and thus a body that is prone to decay. While its life-like qualities are at the centre in contexts where actual death is present or eminent and culturally acquired notions of powerful and protective agents are invoked and reinforced, outside such contexts its life carries associations of death. ${ }^{66}$ Where previous studies have

Menghi: Compendio (as fn. 54), pp. 373f.: "L'essempio chiaro, \& manifesto vediamo in quelli c'hanno gli occhi lippi, \& piangenti li quali alle volte col loro aspetto, \& guardo offendono gli occhi di quelli che gli guardano \& questo avviene perche gli occhi loro sendo infetti di mala qualità infettano l'aria che è frà l'uno, \& l'altro, \& l'aria infettato poi infetta gli occhi che sono incontro a gli occhi dell'infermo".

65 Gregorio Comanini: Il figino, in: Paola Barocchi (ed.): Trattati d'arte del Cinquecento, Bari 1960, vol. 3, pp. 300f:: "Dice [Ficino] di più, che con questi raggi esce un vapore spirituale, e con questo vapore esce sangue; come si conosce dagli occhi lippi e rosseggianti, i quali ammorbano della medesima infermità gli occhi di chi li rimira (la qual cosa non averrebbe, se col raggio non uscisse un vapore di sangue corrot to), e come ancora si può discernere dalla femina menstruata, che con gli sguardi oscura e macchia lo specchio." Cf. Thijs Weststeijn: Seeing and the Transfer of Spirits in Early Modern Art Theory, in: John Hendrix/Charles H. Carman (eds.): Renaissance Theories of Vision, Surrey 2010, pp. 149-169. tion, in: Trends in Cognitive Sciences 7 (2003), pp. 119-124. 


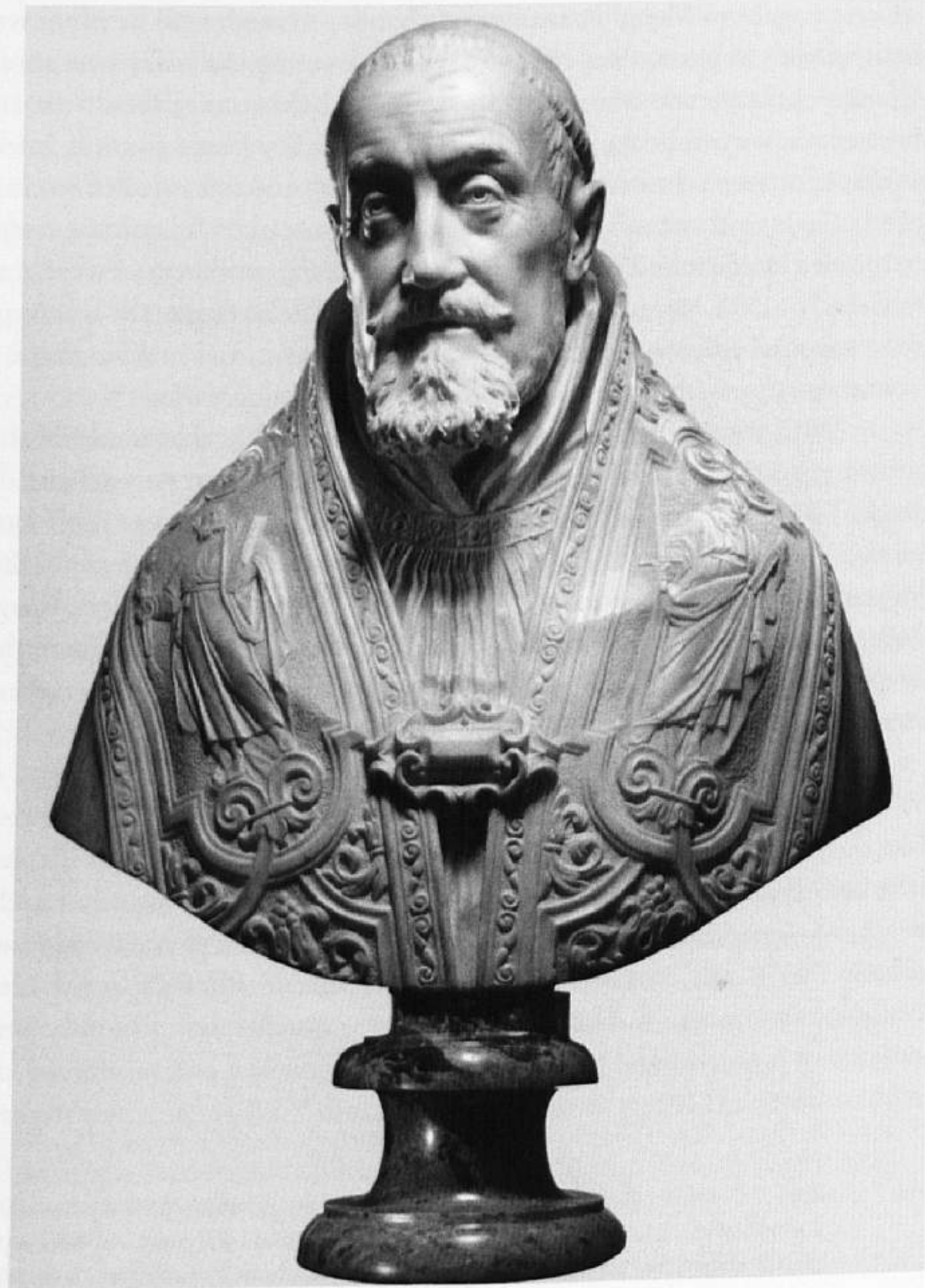

Fig. 5 Gian Lorenzo Bernini: Bust of Pope Gregory XV, 1622-23, marble, $63,5 \mathrm{~cm}$, Toronto, Art Gallery of Ontario.

focused particularly on the role of naturalism, the sources here discussed make clear that this is not all there is to the wax image.

Having said this, it must be stressed that the distinction between "high art" and wax image is not absolute; rather we should think in terms of a continuum. There is always the danger that also the marble bust falls back into the category of the wax portrait. We may note that Matteo Palma stresses in his 
book that the power of the portrait is not confined to wax images alone but also may encompass "cold stone, devoid of graceful colours and liveliness." ${ }^{67}$ Even the works of Bernini may cross over to the other side. In an inventory of the Ludovisi family published by Eva Krems, Bernini's Bust of Pope Gregory XV (Fig. 5) is described as being dressed up "with a cap [berrettino] in red satin and a drape [coperta] of red taffeta [...]." ${ }^{\prime 68}$ As we may recall, the wax image of pope Urban VIII modeled for Centini, too, was clothed with these papal robes, and it seems no coincidence that, as Krems points out, the clothing of the marble bust coincided with the recent death of the pope.

Generally, though, the confines of the aesthetic remain strongly guarded. The marble bust is much more about eternity and purity, indeed a theme that is repeated time and again in contemporary poetry. If it refers to death, it does so in a more abstract, and less physical manner, combining such references with a hint at eternal life. The wax image, to the contrary, flourishes in the realm of death, where, if not for eternity, it manages to contain a life that is both vibrant and organic, powerful but prone to decay.

Palma: Anotomia (as fn. 49), p. 346: "anco dalle fredde pietre prive della gratia colori, e vivezza, si sà [...] esser stato acceso questo fuoco pestifero ne' cuori altrui". Eva-Bettina Krems: Die 'Magnifica Modestia' der Ludovisi auf dem Monte Pincio in Rom. Von der Hermathena zu Berninis Marmorbüste Gregors XV., in: Marburger Jahrbuch für Kunstwissenschaft 29 (2002), p. 138: "Un petto di marmo della S. Memoria di P Gregorio X e V posta su un' scabellone di noce dorato [...] con' un bettettino di raso, rosso, et una Coperta di taffettà rosso lunga p.i 5 , di mano del Bernino." Cf. id., pp. 141f; Philipp Zitzlsperger: Bernini's Bust of Pope Gregory XV. The Reception of a Magic Portrait Cult, in: Sculpture Journal 20 (2011), pp. 223-238. 